\title{
PELATIHAN PENELITIAN TINDAKAN KELAS BAGI GURU-GURU SE-JAKARTA TIMUR
}

\author{
Supria Wiganda \\ Fakultas Teknik Universitas Negeri Jakarta
}

\begin{abstract}
ABSTRAK
Kegiatan pelatihan Penelitian Tindakan Kelas ini bertujuan untuk; Melatih guru-guru terampil dalam membuat karya tulis ilmiah dan melatih guru membuat proposal Penelitian Tindakan Kelas serta, serta melatih guru dapat melaksanakan kegiatan penelitian sebagai upaya dalam pengembangan profesinya.

Khlayak sasaran merupakan Kepala sekolah dan para guru-guru SMK baik negeri maupun swasta se jakarta Timur

Pelatihan ini dilaksanakan dalam beberapa materi pertemuan yang ada kaitannya dengan peneltian tindakan kelas yaitu pedoman penulisan karya tulis ilmiah, prosedur penelitian PTK, Modelmodel pembelajaran serta teknik presentase .yang dilakasanakan pada tanggal 10 oktober 2014 bertempat di SMK negeri 50 Cipinang Jakarta Timur.

Pada Pertemuan tersebut diberikan secara umum tentang meteri penulisan ilmiah, teknik dan prosedur Penelitian Tindakan Kelas serta teknik Presentasi, dan diakhiri dengan pembuatan proposal Penelitian Tindakan Kelas sampai pada siklus-siklusnya.

Kegiatan ini dilaksanakan secara berkesinambungan dengan berbagai intitusi, yang antara lain unsur dinas pendidikan kota administratif jakarta timur, pendidikan menengah kejuruan se wilayah jakarta timur.

Evaluasi kegiatan dilakukan pada saat awal pelatihan, proses pelaksanaan pelatihan, dan diakhir kegiatan tes akhir, serta hasil pekerjanan dalam bentuk proposal PTK.

Dari hasil selama pelatihan berlangsung memperlihatkan keantusiasan peserta sehingga berjalan secara hidup, dan dihasilkan produk proposal PTK dengan bervariasi judul, ini memperlihatkan keberhasilan pelatihan dengan baik.
\end{abstract}

Kata kunci: Peningkatan, PTK, dan Guru SMK

\section{1) PENDAHULUAN}

Pemberlakuan PERMENPAN dan Reformasi Birokrasi no. 16 Tahun 2009 tentang Jabatan Fungsional Guru dan Angka Kriditnya, maka setiap guru yang ingin menaikan pangkatnya diberlakukan untuk membuat Pengembangan Keprofesian Berkelanjutan (PKB) yang salah satunya membuat Penelitian Tindakan Kelas. Selain itu Pemerintah secara resmi telah mencanangkan bahwa profesi guru disejajarkan dengan profesi lainnya sebagai tenaga profesional.

Pengakuan kedudukan guru sebagai tenaga profesional dibuktikan dengan sebuah sertifikat profesi guru yang diperoleh melalui uji sertifikasi. Sertifikat pendidik diberikan kepada guru yang telah memenuhi persyaratan sebagai guru profesional.

Sertifikasi guru juga merupakan salah satu upaya pemerintah dalam meningkatkan kualitas guru sehingga pembelajaran di sekolah menjadi berkualitas. Peningkatan program lain yaitu; peningkatan kualifikasi akademik guru, peningkatan kompetensi guru, pembinaan karir guru, pemberian tunjangan guru, pemberian maslahat tambahan, penghargaan, dan perlindungan guru.

Dalam pelaksanaan PKB hampir tidak pernahguru meneliti bidang pekerjaannya sendiri. Selain itu juga keaktifan dalam mengikuti PKB juga berbagai kegiatan 
penelitian atau karya ilmiah dan sejenisnya yang sangat kurang.

Berdasarkan pada kenyataan di atas dirasa perlu kiranya memberikan pelatihan pada guru dalam kaitannya dengan Penelitian Tindakan Kelas yang merupakan sebagai pengembangan profesi guru.

Atas dasar tersebut diatas maka dapat dirumuskan Apakah dengan mengikuti pelatihan guru dapat membuat proposal penelitian tindakan kelas?, dan apakah dengan mengikuti pelatihan guru dapat melaksanakan penelitian tindakan kelas?

SedangkanTujuan kegiatan ini adalah sebagai berikut:Melatih Guru membuat proposal Penelitian Tindakan Kelas, merencanakanPenelitian Tindakan Kelas sebagai usaha pengembangan profesi,dan dapat melaksanakan PenelitianTindakan Kelas sebagai salah satu bahan untuk kenaikan pangkatnya.

\section{A. Hakikat Penelitian Tindakan Kelas}

Perkembangan penelitian akhir-akhir ini sangat pesat melalui berbagai kajian permasalahan. Metode-metode, teori-teori ataupun hasil penelitian telah terakumulasi sehingga membentuk tradisi penelitian yang berbeda dengan yang selama ini dilakukan.

Penelitian Tindakan Kelas (PTK) pertama kali diperkenalkan oleh ahli psikologi sosial Amerika yang bernama Kurt Lewin pada tahun 1946. Inti gagasan Lewin inilah yang selanjutnya dikembangkan oleh ahli-ahli lain seperti Stephen Kemmis, Robin McTaggart, John Elliot, Dave Ebbutt, dan sebagainya.

Jenis penelitian ini dapat dilakukan di dalam bidang pengembangan organisasi, manajemen, kesehatan atau kedokteran, pendidikan, dan sebagainya. Di dalam bidang pendidikan penelitian ini dapat dilakukan pada skala makro ataupun mikro. Dalam skala mikro misalnya dilakukan di dalam kelas pada waktu berlangsungnya suatu kegiatan belajarmengajar untuk suatu pokok bahasan tertentu pada suatu mata kuliah. Untuk lebih detailnya berikut ini akan dikemukakan mengenai hakikat PTK.
Pendapat yang dikemukakan oleh Kemmis dan McTaggart (1988), yang mengatakan bahwa PTK adalah suatu bentuk refleksi diri kolektif yang dilakukan oleh peserta-pesertanya dalam situasi sosial untuk meningkatkan penalaran dan keadilan praktikpraktik itu dan terhadap situasi tempat dilakukan praktik -praktik tersebut.

Menurut Carr dan Kemmis seperti yang dikutip oleh Siswojo Hardjodipuro, dikatakan bahwa yang dimaksud dengan istilah PTK adalah suatu bentuk refleksi diri yang dilakukan oleh para partisipan (guru, siswa atau kepala sekolah) dalam situasi-situasi sosial (termasuk pendidi-kan) untuk memperbaiki rasionalitas dan kebenaran (a) praktik-praktik sosial atau pendidikan yang dilakukan sendiri, (b) pengertian mengenai praktik-praktik ini, dan (c) situasi- situasi (dan lembaga-lembaga) tempat praktik-praktik tersebut dilaksanakan (Hardjodipuro, 1997).

Dari pengalaman empat tahun ini ada variasi kepemimpinan kelompok PTK. Variasi pertama adalah guru inti/instruktur yang memimpin kelompok PTK, kegiatannya dititikberatkan pada pemberian contoh melakukan PTK yang baik. Variasi kedua adalah kepala sekolah yang memimpin kelompok PTK, kegiatannyadititikberatkan pada masalah manajemen. Pengalaman menunjukkan bahwa variasi kedua cenderung lebih efektif dari yang pertama.

PTK sangat bermanfaat bagi guru untuk meningkatkan mutu proses dan hasil pembelajaran di kelas. Dengan melaksanakan tahapan-tahapan PTK, guru dapat menemukan solusi dari masalah yang timbul di kelasnya sendiri, bukan kelas orang lain, dengan menerapkan berbagai ragam teori dan teknik pembelajaran yang relevan secara kreatif. Selain itu sebagai penelitian terapan, di samping guru melaksanakan tugas utamanya mengajar di kelas, tidak perlu harus meninggalkan siswanya. Jadi PTK merupakan suatu penelitian yang mengangkat masalahmasalah aktual yang dihadapi oleh guru di lapangan. Dengan melaksanakan PTK, guru 
mempunyai peran ganda : praktisi dan peneliti

Sebagai paradigma sebuah penelitian tersendiri, PTK memiliki karakteristik yang relatif agak berbeda jika dibandingkan dengan jenis penelitian yang lain, misalnya penelitian naturalistik, eksperimen, survei, analisis isi, dan sebagainya. Jika dikaitkan dengan jenis penelitian yang lain PTK dapat dikategorikan sebagai jenis penelitian kualitatif dan eksperimen. PTK dikategorikan sebagai penelitian kualitatif karena pada saat data dianalisis digunakan pendekatan kualitatif, tanpa adanya perhitungan statistik.

Dikatakan sebagai penelitian eksperirnen, karena penelitian ini diawali dengan perencanaan, adanya perlakuan terhadap subjek penelitian, dan adanya evaluasi terhadap hasil yang dicapai sesudah adanya perlakuan.

Ditinjau dari karakteristiknya, PTK setidaknya memiliki karakteristik antara lain: (1) didasarkan pada masalah yang dihadapi guru dalam pembelajaran; (2) adanya kolaborasi dalam pelaksanaannya; (3) peneliti sekaligus sebagai praktisi yang melakukan refleksi; (4) bertujuan memperbaiki dan atau meningkatkan kualitas praktek instruksional; (5) dilaksanakan dalam rangkaian langkah dengan beberapa siklus.

\section{B. Hakekat Pengembangan Profesi}

Pekerjaan profeisonal dapat dikelompokkan ke dalam dua katagori: yaitu Hard Profession dan Soft Profession. Suatu pekerjaan dapat dapat dikatagorikan sebagai Hard Profession apabila pekerjaan tersebut dapat didetailkan dalam perilaku dan langkahlangkah yang jelas dan yang relatif pasti. Pendidikan yang diperlukan bagi profesi ini adalah menghasilkan keluaran pendidikan yang dapat distandarisasikan. Artinya, kualifikasi lulusan jelas dan seragam di manapun pendidikan itu berlangsung.

Dengan kulifikasi ini seseorang sudah mampu dan akan terus mampu melaksanakan tugas profesinya secara mandiri tanpa pendidikan lagi. Pekerjaan dokter dan pilot sebagai contohnya. Sebaliknya katagori Soft Profession adalah diperlukannya kadar seni dalam melasanakaan pekerjaan tersebut. Ciri pekerjaan tersebut tidak dapat dijabarkan secara detail dan pasti. Sebab, langkah-langkah dan tindakan yang harus diambil, sangat ditentukan oleh kondisi dan stuasi tertentu. Implikasi katagori Soft Profession tidak menuntut pendidikan yang dapat menghasilkan lulusan dengan standar tertentu melainkan menuntut lulusan dibekali dengan kemampuan minimal. Kemampuan ini dari waktu ke waktu harus ditingkatkan agar dapat melaksanakan tugas pekerjaannya sesuai dengan perkembangan masyarakat.

Oleh karena itu, lembaga in - service training bagi Soft Profession amat penting. Profesi Guru termasuk dalam katagori Soft Profession. Sehingga dirasakan perlu atau secara rasonal dapat kiranya program sertifikasi guru ini dibenarkan. Karena dengan program sertifikasi ini akan membawa kepada mutu pendidikan yang lebih baik.

Sertifikasi guru merupakan salah satu upaya pemerintah dalam meningkatkan kualitas guru sehingga pembelajaran di sekolah menjadi berkualitas. Peningkatan program lain yaitu; peningkatan kualifikasi akademik guru menjadi S1/D4, peningkatan kompetensi guru, pembinaan karir guru, pemberian tunjangan guru, pemberian maslahat tambahan, penghargaan, dan perlindungan guru. Tugas seorang guru dilihat dari profesi adalah : a) Mendidik: Meneruskan dan mengembangkan nilai-nilai hidup. b) Mengajar: Meneruskan dan mengembangkan iptek. c) Melatih: Mengembangkan keterampilan dan penerapannya. Sementara tugas seorang guru sebagai tugas kemanusiaan adalah: a)Menjadi orang tua kedua, b) Transformasi diri, dan c) Autoidentifikasi. Guru juga mengemban tugas kemasyarakatan yang antara lain: Mendidik dan mengajar masyarakat untuk menjadi WNI yang bermoral Pancasila, dan Mencerdaskan bangsa Indonesia

Guru profesional dan bermartabat menjadi impian kita semua karena akan melahirkan anak bangsa yang cerdas, kritis, 
inovatif, demokratis, dan berakhlak. Guru profesional dan bermartabat memberikan teladan bagi terbentuknya kualitas sumber daya manusia yang kuat. Sertifikasi guru mendulang harapan agar terwujudnya impian tersebut. Perwujudan impian ini tidak seperti membalik talapak tangan. Karena itu, perlu kerja keras dan sinergi dari semua pihak yakni, pemerintah pusat, pemerintah daerah, masyarakat, dan guru.

Didalam undang-undang guru dan dosen dinyatakan ada empat kompetensi profesi guru yaitu: 1. Kompetensi Pedagogik, Kemampuan mengelola pembelajaran peserta didik. 2. Kompetensi Kepribadian, Kemampuan kepribadian yang mantap,berakhlak mulia, arif dan berwibawa serta menjadi teladan peserta didik. 3. Kompetensi Profesional, Kemampuan penguasaan materi pelajaran secara luas dan mendalam. dan 4. Kompetensi Sosial, Kemampuan untuk berkomunikasi dan berinteraksi secara efektif dan efisien dengan peserta didik, sesama guru, orangtua/wali dan masyarakat sekitar. Keempat komponen kompetensi guru ini dijabarkan ke dalam 10 kompetensi.

Selain hal tersebut di atas kita juga mengenal 10 kompetensi guru yaitu: 1) Menguasai bahan pelajaran, 2) Mengelola PBM, 3) Mengelola Kelas, 4)Menggunakan media/sumber belajar, 5) Mengguasai landasan pendidikan, 6) Mengelola interaksi belajar mengajar, 7) Menilai prestasi siswa, 8) Mengenal layanan BK, 9) Mengenal Penyelenggaraan. Administrasi Sekolah, dan 10) Memahami prinsip-prinsip Penelitian Pendidikan.

Sertifikasi guru melalui uji kompetensi memperhitungkan pengalaman profesionalitas guru, melalui penilaian portofolio guru. Sepuluh komponen portofolio guru akan dinilai oleh perguruan tinggi penyelenggara sertifikasi guru.

\section{Hakekat Karya Tulis Ilmiah}

Karya tulis ilmiah adalah suatu karya tulis yang dibuat beracuan pada proses ilmiah.
Suatu karya ilmiah (scientific paper) adalah laporan tertulis dan dipublikasi yang memaparkan hasil penelitian atau pengkajian yang telah dilakukan oleh seseorang atau sebuah tim dengan memenuhi kaidah dan etika keilmuan yang dikukuhkan dan ditaati oleh masyarakat keilmuan. Terdapat berbagai jenis karangan ilmiah, antara lain laporan penelitian, makalah seminar atau simposium,artikel jurnal, yang pada dasarnya kesemuanya itu merupakan produk dari kegiatan ilmuwan. Data, simpulan, dan informasi lain yang terkandung dalam karya ilmiah tersebut dijadikan acuan (referensi) bagi ilmuwan lain dalam melaksanakan penelitian atau pengkajian selanjutnya.

Sistematika suatu karya ilmiah sangat perlu disesuaikan dengan sistematika yang diminta oleh media publikasi (jurnal atau majalah ilmiah), sebab bila tidak sesuai akan sulit untuk dimuat. Sedangkan suatu karya ilmiah tidak ada artinya sebelum dipublikasi. Walaupun ada keragaman permintaan penerbit tentang sistematika karya ilmiah yang akan dipublikasi, namun pada umumnya meminta penulis untuk menjawab empat pertanyaan berikut: (1) Apa yang menjadi masalah?; (2) Kerangka acuan teoretik apa yang dipakai untuk memecahkan masalah?; (3) Bagaimana cara yang telah dilakukan untuk memecahkan masalah itu?; (4) Apa yang ditemukan?; serta (5) Makna apa yang dapat diambil dari temuan itu?

Paparan tentang apa yang menjadi masalah dengan latar belakangnya biasanya dikemas dalam bagian Pendahuluan. Paparan tentang kerangka acuan teoretik yang digunakan dalam memecahkan masalah umumya dikemukakan dalan bagian dengan judul Kerangka Teoritis atau Teori atau Landasan Teori, atau Telaah Kepustakaan, atau label-label lain yang semacamnya. Paparan mengenai apa yang dilakukan dikemas dalam bagian yang seringkali diberi judul Metode atau Metodologi atau Prosedur atau Bahan dan Metode. Jawaban terhadap pertanyaan apa yang ditemukan umumnya dikemukakan dalam bagian Temuan atau 
Hasil Penelitian. Sementara itu paparan tentang makna dari temuan penelitian umumnya dikemukakan dalam bagian Diskusi atau Pembahasan. Tentu saja sistematika karya ilmiah ini tidak baku, atau harga mati. Sistematika karya ilmiah sangat bergantung pada tradisi masarakat keilmuan dalam bidang terkait, jenis karya ilmiah (makalah, laporan penelitian, skripsi). Dalam suatu karya ilmiah yang mempunyai tingkat keformalan yang tinggi, seperti misalnya skripsi, sistematika penulisan lebih baku, dan beberapa paparan lainnya sering diminta dari mahasiswa, seperti seperti Kesimpulan dan Rekomendasi (SaranSaran) pada bagian akhir, atau Kata Pengantar pada bagian awal.

Banyak jurnal dan majalah meminta abstrak, yakni rangkuman informasi yang ada dalam dokumen laporan, makalah, atau skripsi, lengkapnya. Abstrak yang ditulis secara baik memungkinkan pembaca mengenali isi dokumen lengkap secara secara cepat dan akurat, untuk menentukan apakah isi dokumen sesuai dengan bidang minatnya, sehingga dokumen tersebut perlu dibaca lebih lanjut. Abstrak sebaiknya tidak lebih dari 250 kata (dalam satu atau dua paragraf), menyatakan secara singkat tujuan dan lingkup penelitian/pengkajian, metode yang digunakan, rangkuman hasil, serta kesimpulan yang ditarik.

\section{METODOLOGI}

Pemecahan masalah tentang Peningkatan Layanan Pendidikan Dalam Proses Pembelajaran di Sekolah dengan mengadakan pelaksanakan pelatihan Penelitian Tindakan Kelas bagi guru- guru SMK dalam dua tahap, yaitu tahap pertama tentang pemberian materi teori secara keseluruhan dan tahapan berikutnya adalah latihan membuat proposal penelitian PTK sampai berhasil menjadi produk.

Adapun peserta dalam pelatihan ini adalah Kepala Sekolah dan Guru-guru yang akan mengusulkan naik pangkat atau sedang menyelesaikan program pendidikan di pendidikan tinggi sebagai contoh mahasiswa yang dalam hal ini adalah guru yang sedang membuat skripsi, Tesis maupun Disertasinya.

Pelaksanaannya sebanyak 6 kali latihan/pertemuan yang masing-masing selama 1,5 jam. Pada pertemuan pertama diberikan secara umum tentang penelitian tindakan kelas. Pada pertemuan 2 sampai ke 5 latihan penerapan pembuatan proposal sampai pada penerapan siklus siklus penelitian dan pertemuan ke 6 evaluasi.

Banyak manfaat yang dapat diperoleh dari kegiatan ini yaitu antara lain :

1) Memudahkanguruyang masih berstatus mahasiswa dalammenyelesaikan tugas akhir di program pendidikan tinggi.

2) Mempercepat proses pembuatan Penelitian Tindakan Kelassebagaipengembangan profesi berkelanjutan bagi guru.

3) Guru mempunyai keterampilan dalam membuat Penelitian Tindakan Kelasberdasarkan pada pengembangan profesi guru.

\section{HASIL DAN PEMBAHASAN}

Evaluasi kegiatan dilakukan tidak saja di akhir dari program pelatihan juga selama proses dilakukan juga evaluasi pada peserta pelatihan. Jadi di awal program diberikan tes awal, di sepanjang pelatihan ada kuis tiap bahasan, dan diakhir program juga ada tes akhir. Serta juga hasil pekerjaan selama proses pelatihan dalam bentuk proposal penelitian.

Dari hasil observasi selama pelatihan berlangasung memperlihatkan keseriusan dan keantusiasan peserta sehingga interaktif berjalan secara hidup dan produk proposal yang dihasilkanpun sangat baik dan berpariatif.

Berikut ini dipaparkan hasil kegisatan program pengabdian masyarakat untuk guruguru SMK se jakarta Timur:Pada kegiatan ini diadakan evaluasi terhadap peserta dan evaluasi terhadap program kegiatan. Evaluasi terhadap peserta dilakukan oleh anggota tim terhadap proses dan hasil yang dicapai secara 
obyektif. Sedangkan Evaluasi terhadap program kegiatan dilakukan oleh pelaksana untuk mengetahui tingkat ketercapaian tujuan kegiatan yang dilaksanakan.

Kegiatan evaluasi dilaksanakan sebelum, selama dan sesudah kegiatan pelatihan ini berlangsung. Evaluasi sebelum kegiatan dilakasanakan dengan cara diskusi dengan para anggota sebelum pelaksanakaan pemaparan materi; sedangkan evaluasi selama kegiatan berlangsung dilakaukan dengan mengamati peserta paltihan. Dan setelah itu di;akukan evaluasi dengan cara membuat masing-masing proposal PTK yang akan diajukan pada penelitian masing-masing.

Atas dasar pengamatan selama pelaksanaan pelatihan berlangsung seluruh peserta sangat perhatian dan serius dalam membuat tugasnya serta adanya perubahan perilaku dalam berdiskusi yang cukup baik . Yang saat awal pertemuan belum terbuka wawasannya tentang pengetahuan PTK, sekarang cukup memiliki kemampuan untuk menulis sebuah proposal penelitian PTK, hal ini mengindikasikan bahwa pelatihan yang diadakan sudah cukup berhasil.

Selain itu dapat terlihat dengan berbagai variasi judul proposal yang dihasilkan oleh para peserta, juga memperlihatkan bahwa kemampuan para peserta dalam memecahkan berbagai masalah di kelas melalui sebuah penelitiannya, sehingga memperlihatkan kemampuan atau keberhasilan yang sangat baik bagi peserta.Adapun faktor pendorong dalam kegiatan ini adalah adanya kesungguhan dari seluruh peserta guru-guru SMK serta Kepala Sekolah SMK masing yang telah memberikan izin dan tugas kepada gurugurunya. Juga Kepala Sekolah SMKN 50 Jakarta yang telah memberikan kesempatan untuk menjadi tuan rumah dalam pelaksanaan pelatihan serta membantu berbagai sarana prasarana dan akomodasi demi kelancaran pelaksanaan pelatihan PTKdi wilayah Jakarta Timur yang telah diberikan kepada pelaksana Pengabdian Masyarakat LPM Universitas Negeri Jakarta, sehingga berjalan sesuai dengan jadwal yang telah ditentukan sebelumnya.

Adapun faktor penghambat dalam pelatihan ini dapat dikatakan tidak ada, kecuali faktor dana yang terbatas, sehingga jumlah peserta dibatasi, sarana prasara yang diberikan kepada para peserta pelatihan juga kepada para pelatihan sangat terbatas pula.

\section{KESIMPULAN}

Sebagai simpulan dari hasil kegiatan pelatihan Penelitian Tindakan Kelas kali ini adalah Para peserta mengetahui konsep dasar PTK secara mendalam, sehingga memiliki kemampuan untuk membuat suatu penelitian PTK dalam bentuk proposal, Dengan adanya berbagai variasi judul dalam proposal PTKyang telah dibuat para peserta, mengindikasikan bahwa wawasan serta kemampuan mengenai PTK bagi peserta ternyata meningkat, dan Hasil pelatihan dapat diaplikasikan secara jelas, dan juga dapat membantu/ mempercepat dalam penulisan karya ilmiah lain bagi guru-guru yang sedang membuat tesis maupun disertasinya.

\section{DAFTAR PUSTAKA}

[1] APA, 1983. Publication Manual of theAmerican Psychological AssociationThird Edition. Washington DC: American Psychological Association.

[2] Barlow, Daniel Lenox. 1985. Educational Psychology: The Teaching LearningProcees. Chiocago: The Moody Bible Institute.

[3] Bloom, Benyamin S. 1976. Human Characteristic and School Learning. New York: Mc Graw-Hill Book Company.

[4] Hopkins, D. 1985. A Teacher"s. Guide to Classroom Research. Philadelphia: Open University Press.

[5] Santoso, Singgih. 2000. Buku Latihan SPSS Statistik Parametrik. Jakarta: Elex Media Komputindo. 
[6] Suwarsih Madya. 2006. Teori dan Praktik Penelitian Tindakan. Bandung: Alfabeta.

[7] Thorndike R.L \& E.P. Hagen, 1977. Measurement and Evaluation in Psychology and Education. New York: John Wiley \& Sons.
[8] Wilkinson, David, 2000. The Researcher's Toolkit The Complete Guide toPractioner Research. London: Routledge Falmer 